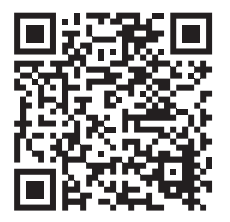

* Cirugía General y Laparoscopia. Hospital Ángeles Metropolitano, Ciudad de México.

Correspondencia: JAPCV, jope_@yahoo.com Conflicto de intereses: Ninguno.

Citar como: Pérez CVJA. In Memoriam Acad. Dr. Héctor Aguirre Gas. Rev CONAMED. 2021; 26(4): 204-205. https://dx.doi. org/10.35366/102509

Financiamiento: Ninguno.

Recibido: 25/10/2021. Aceptado: 25/10/2021.

\section{In Memoriam Acad. Dr. Héctor Aguirre Gas}

\author{
In Memoriam Professor Héctor Aguirre Gas, MD
}

Jorge A Pérez Castro y Vázquez*

Evocar a un maestro, líder, directivo, compañero de trabajo, amigo con quien se pueden compartir intereses comunes, ideas y aspiraciones, sin trabas y con plena confianza de que serás escuchado y que obtendrás una retroalimentación mesurada, centrada y enfocada, ha sido una experiencia singular que se agradece a la vida.

Muchas han sido las palabras motivadas por la reciente ausencia terrenal del Dr. Héctor Aguirre Gas (Figura 7), se ha señalado su trayectoria profesional como internista, directivo, sus trabajos sobre calidad que marcaron un hito en la historia de la medicina en nuestro país e internacionalmente, llegando a ser un pilar de la mística que aun hoy subyace en el cambiante Instituto Mexicano del Seguro Social, su espíritu institucional, su trabajo incansable, sus definiciones y conceptos, su visión de solidaridad, su deseo de una mejor medicina y mejores profesionales de la salud, un ejemplo de ello es su muy difundida plática sobre el virus de la soberbia humana (VSH), ¿una nueva enfermedad?, de la que ahora reproduzco como homenaje a su perenne pensamiento:

Se presenta la descripción de una nueva enfermedad y se indican sus síntomas, signos, resultados de laboratorio, de gabinete y respuesta a algunos procedimientos terapéuticos. Afecta inicialmente al sistema nervioso central, empezando por los pares craneales y la corteza cerebral; sin embargo, evoluciona progresivamente hacia una enfermedad multisistémica. Afecta a individuos de ambos sexos, con mayor frecuencia entre los 16 y 75 años, que laboran en instituciones públicas o privadas, ocupando posiciones de elevado nivel jerárquico. Por sus diferentes grados de gravedad y mala respuesta a las medidas terapéuticas es necesario llevar a cabo una difusión de sus principales signos y síntomas, que permita realizar una prevención oportuna y suficiente y así evitar o detener su evolución en etapas tempranas.

El propósito de la presente comunicación es alertar a las personas que se encuentran en las alturas o que han ascendido por la escalera de la vida en forma rápida o a saltos, que caminan por el terreno de la infalibilidad o se deleitan con las mieles del poder, y recordarles que es preferible prevenir que tener que aceptar las consecuencias de una terrible enfermedad que puede acabar con ellos o dejarles secuelas permanentes.

Para terminar, vale la pena dejar la parte final del trabajo que tiene gran significado de la calidad de ser humano que fue el Dr. Héctor Aguirre Gas. ... no debe 
olvidarse que lo importante no es identificarla en los demás, sino en nosotros mismos y que si no identificamos en nosotros ningún síntoma que

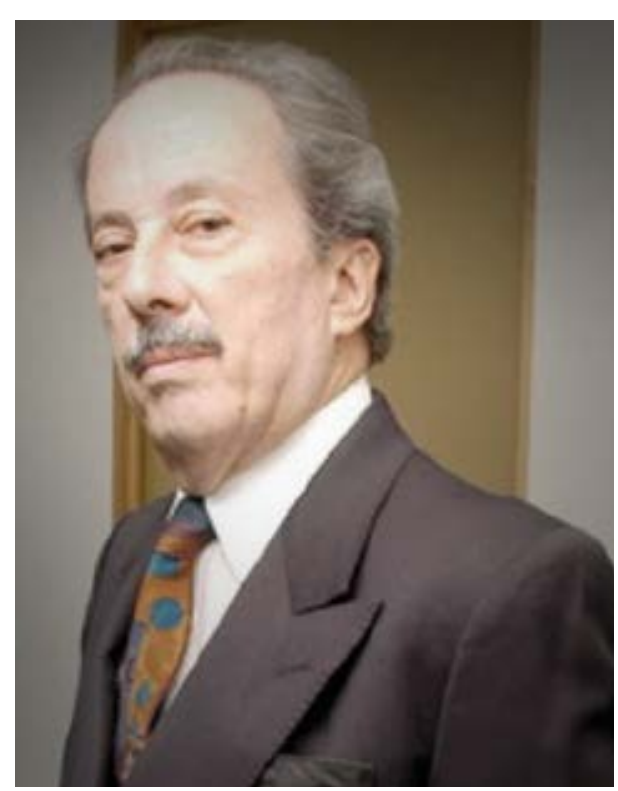

Figura 1: Acad. Dr. Héctor Aguirre Gas. nos preocupe, pudiera deberse a que ya estamos enfermos y somos incapaces de reconocer sus manifestaciones en nosotros mismos. Concluyo refiriendo a ustedes que me retiro a continuar mis investigaciones sobre esta enfermedad, puesto que se ha descrito un nuevo síntoma: a los enfermos por el VSH les da por describir enfermedades de los demás... Aguirre Gas, Héctor G. VSH ¿Una nueva enfermedad? http://www.medigraphic.com/ pdfs/facmed/un-2001/un013i.pdf

También se ha escrito sobre el médico, hombre serio, culto, mesurado, siempre pulcro, quizás hasta reservado, pero siempre con el don de ser humano sensible a la injusticia y a la impunidad, e impotencia que la vida nos presenta y que siempre supo afrontar con valor y categoría.

Finalizo resaltando que es un don de la vida poder dejar un legado a nuestra partida, el Dr. Héctor Aguirre Gas lo tuvo y fue generoso con los que lo conocimos y disfrutamos de su saber, amistad y compañía y también para quienes no lo conocieron, pero que disfrutan de muchos de sus anhelos que hoy son realidades en la vida del profesional de la salud. 